JURNAL IKA : IKATAN ALUMNI PGSD UNARS

Vol. 9 No. 1, Juni 2021

P-ISSN :2338-3860

https://unars.ac.id/ojs/index.php/pgsdunars/index

\title{
PENGARUH KONSENTRASI DAN INTENSITAS BELAJAR TERHADAP KEMAMPUAN BERFIKIR KRITIS PESERTA DIDIK PADA MATA PELAJARAN EKONOMI DI MA SARJI AR RASYID DAWUHAN
}

\author{
Dassucik $^{1}$ Jhon Harisantoso ${ }^{2}$ \\ ${ }^{1,2}$ STKIP PGRI SITUBONDO \\ Correspondence Email: dassucik75@ gmail.com
}

Received: May 11, 2020 Revised: May 14, $2020 \quad$ Accepted: May 18, 2020

\begin{abstract}
ABSTRAK
Tujuan dari penelitian ini untuk mengetahui pengaruh konsentrasi dan intensitas belajar terhadap kemampuan berfikir kritis peserta didik pada mata pelajaran ekonomi di MA Sarji Ar Rasyid Dawuhan Situbondo semester ganjil tahun pelajaran 2020/2021. Dalam penelitian ini rancangan yang digunakan adalah rancangan expost facto. Berdasarkan hasil analisis data dan pengujian hipotesis, didapat nilai tingkat koefisien korelasi antara kedua variabel bebas secara serempak dengan kriteriumnya yaitu berdasarkan data diatas dengan ketentuan tingkat kesalahan $\alpha=0,05$; di dapat $\mathrm{F}$ hitung $=25,06$ sedangkan $\mathrm{F}$ tabel $=3,130$. Ternyata $\mathrm{F}$ hitung $\geq \mathrm{F}$ tabel atau 134,894 $\geq 3,130$ maka ada pengaruh yang signifikan variabel pengaruh konsentrasi dan intensitas belajar terhadap kemampuan berfikir kritis peserta didik. Hasil perhitungan korelasi ganda product moment dari Pearson, dan didukung dengan bantuan program SPSS diatas didapat nilai r hitung sebesar 0,894.

Kata Kunci: Konsentrasi, Intensitas belajar dan kemampuan berpikir kritis.

\section{PENDAHULUAN}

Proses pembelajaran dikatakan berhasil jika tujuan pembelajaran itu tercapai. Berhasil tidaknya pencapaian tujuan pembelajaran tergantung pada proses pembelajaran yang dijalani oleh peserta didik. Menurut Asmani (2013: 27) ada dua indikator yang dapat dijadikan sebagai tolak ukur keberhasilan proses belajar yaitu daya serap terhadap pelajaran dan perubahan perilaku peserta didik. Salah satu faktor yang dapat mempengaruhi rendahnya daya serap peserta didik adalah konsentrasi belajar. Daud menyatakan konsentrasi belajar merupakan pemusatan perhatian dalam
\end{abstract}


proses perubahan tingkah laku yang dinyatakan dalam bentuk penguasaan, penggunaan, dan penilaian terhadap sikap dan nilai - nilai, pengetahuan dan kecakapan dasar yang terdapat dalam berbagai bidang studi. Secara teoritis jika konsentrasi belajar peserta didik rendah, maka akan menimbulkan aktivitas yang berkualitas rendah pula serta dapat menimbulkan ketidakseriusan dalam belajar (2012 :34).

Perkataan intensitas sangat erat kaitannya dengan motivasi, antara keduanya tidak dapat dipisahkan sebab untuk terjadinya intesitas belajar atau semangat belajar harus di dahului dengan adanya intensitas atau semangat belajar yang tinggi terutama didasarkan adanya motivasi. Makin tepat motivasi yang diberikan, akan makin berhasil pula pelajaran itu. Jadi Motivasi akan senantiasa menentukan intensitas belajar siswa. Intensitas merupakan realitas dari motivasi dalam rangka mencapai tujuan yang diharapkan yaitu peningkatan kemampuan berpikir kritisnya, sebab seseorang melakukan usaha dengan penuh semangat karena adanya motivasi sebagai pendorong pencapaian kemampuan berpikir kritis peserta didik.

Berfikir kritis mempunyai peran yang sangat penting bagi peserta didik untuk menentukan keberhasilan dalam proses belajar mengajar atau bisa diartikan sebagai pemikiran sendiri untuk memastikan dan menganalisis peserta didik dengan tujuan menarik kesimpulan yang cerdas. Berfikir kritis merupakan proses dan kemampuan yang melibatkan dalam membuat keputusan diri sendiri untuk menghadapi setiap permasalahan dalam menentukan keputusan yang terbaik.

Berhubungan dengan berfikir kritis akan di latih pikirannya dalam mengamati masalah, menganalisis, dan memecahkan setiap masalah yang ada pada setiap pembelajaran. Seseorang yang berfikir kritis bukan berarti berfikir keras melainkan berfikir lebih baik untuk mengasah keingintahuannya dengan berani berpendapat dan memiliki ide- ide baru atau konsep dalam menentukan sebuah keputusan.

\section{METODE PENELITIAN}

Untuk membantu dan menunjang penelitian ini, metode yang digunakan yaitu metode angket. angket yang digunakan oleh peneliti berbentuk pertanyaan tertutup, 
dimana responden hanya memberi jawaban yang tersedia dalam angket. Sampel dalam penelitian ini siswa kelas $\mathrm{X}$ dan XI di MA Sarji Ar Rasyid Dawuhan Situbondo yang berjumlah 71 peserta didik. Setelah data diperoleh selanjutnya yaitu analisa data. Analisa data yang digunakan dalam penelitian ini yaitu dengan Uji prasyarat dan Uji hipotesis dengan bantuan aplikasi SPSS. SPSS for Windows release 20.0

Adapun tahapan yang dilakukan sebagai berikut :

a. Uji Prasyarat

1. Uji validitas, tahapan awal untuk menguji valid tidaknya suatu instrumen yang digunakan. Dengan bantuan SPSS menggunakan rumus korelasi Product Moment Pearson.

2. Uji reliabilitas, mengetahui akurasi pertanyaan dalam menghasilkan data yang reliabel. Uji reliabilitas angket menggunakan reliabilitas Cronbach's Alpha.

3. Uji normalitas, untuk menguji apakah data yang bersangkutan berdisribusi normal atau tidak. Menggunakan rumus One-Sample KolmogorovSmirnov.

4. Uji linearitas, mengetahui apakah dua variabel mempunyai hubungan yang linear secara signifikan atau tidak.

b. Uji Hipotesis

Tahapan awal menggunakan analisis korelasi sederhana dan dilanjutkan dengan analisis korelasi berganda. Uji hipotesis digunakan untuk mengetahui korelasi antar variabel.

\section{HASIL DAN PEMBAHASAN}

Dalam penulisan ini terdapat beberapa tahapan dalam proses analisa data antara lain :

a. Uji Prasyarat

\section{Uji Validitas}

Peneliti menguji validitas angket sejumlah 71 peserta didik dari kelas $\mathrm{X}$ dan XI MA Sarji Ar Rasyid Dawuhan Situbondo. 
Tabel 1. Hasil Validitas Angket Konsentrasi Belajar (Variabel $\mathrm{X}_{1}$ )

\begin{tabular}{|c|c|c|c|}
\hline Butir Soal & r hitung & r tabel & Interpretasi \\
\hline 1 & 0,966 & $\geq 0,235$ & Valid \\
\hline 2 & 0,433 & $\geq 0,235$ & Valid \\
\hline 3 & 0,931 & $\geq 0,235$ & Valid \\
\hline 4 & 0,939 & $\geq 0,235$ & Valid \\
\hline 5 & 0,924 & $\geq 0,235$ & Valid \\
\hline 6 & 0,914 & $\geq 0,235$ & Valid \\
\hline 7 & 0,903 & $\geq 0,235$ & Valid \\
\hline 8 & 0,926 & $\geq 0,235$ & Valid \\
\hline 9 & 0,927 & $\geq 0,235$ & Valid \\
\hline
\end{tabular}

Tabel 2. Hasil Validitas Angket Intensitas Belajar (Variabel $\mathrm{X}_{2}$ )

\begin{tabular}{|c|c|c|c|}
\hline Butir Soal & r hitung & r tabel & Interpretasi \\
\hline 1 & 0,898 & $\geq 0,235$ & Valid \\
\hline 2 & 0,944 & $\geq 0,235$ & Valid \\
\hline 3 & 0,917 & $\geq 0,235$ & Valid \\
\hline 4 & 0,920 & $\geq 0,235$ & Valid \\
\hline 5 & 0,869 & $\geq 0,235$ & Valid \\
\hline 6 & 0,935 & $\geq 0,235$ & Valid \\
\hline 7 & 0,915 & $\geq 0,235$ & Valid \\
\hline 8 & 0,954 & $\geq 0,235$ & Valid \\
\hline 9 & 0,941 & $\geq 0,235$ & Valid \\
\hline
\end{tabular}

Keterangan: Soal dinyatakan valid jika hasil $r_{\text {hitung }}>r_{\text {tabel }}$ atau $r_{\text {tabel }}=$ taraf $s i g$ 0,05. Dari masing-masing hasil nilai korelasi tersebut, kemudian dikonsultasikan dengan nilai $\mathrm{r}$ tabel pada taraf signifikansi $5 \%$ dan pada $\mathrm{db}=\mathrm{N}-1=71-1=70$, dimana $r$ tabelnya $\left(r_{\text {tab }}\right)$ sebesar 0,235 , sehingga dapat dilihat. Jika besar $r$ hitung $\left(r_{\text {hit }}\right)$ 
lebih kecil dari pada $\mathrm{r}$ tabel $\left(\mathrm{r}_{\mathrm{tab}}\right)$, maka soal tersebut tidak valid dan perlu di revisi, tetapi apabila $\mathrm{r}$ hitung $\left(\mathrm{r}_{\text {hit }}\right)$ lebih besar daripada $\mathrm{r}$ tabel $\left(\mathrm{r}_{\mathrm{tab}}\right)$ maka soal tersebut dapat dikatakan valid.

Berdasarkan hasil analisis di atas, dapat dilihat seluruh soal angket konsentrasi belajar dan intensitas belajar dinyatakan valid, karena $r_{\text {hitung }}>r_{\text {tabel. }}$. Sehingga soal tersebut sudah dapat digunakan lebih lanjut untuk penelitian.

\section{b. Uji Reliabilitas}

Uji reliabilitas bertujuan untuk mengetahui keandalan kuesioner yaitu sejauh mana suatu alat pengukur dapat dipercaya atau diandalkan dan tetap konsisten jika dilakukan dua kali atau lebih pada kelompok yang sama dengan alat ukur yang sama. Pengujian Cronbach Alpha digunakan untuk menguji tingkat keandalan (reliability) dari masing-masing angket variabel. Data diolah dengan bantuan Microsoft Excel dan program SPSS for Windows release 20.0

Setelah mendapatkan hasil dari uji validitas instrumen, langkah selanjutnya adalah melakukan uji reliabilitas pada kuesioner 9 soal konsentrasi belajar dan 9 soal intensitas belajar. Untuk lebih jelasnya akan penulis uraikan hasil uji reabilitas pada tabel berikut:

Tabel 3. Hasil Uji Reliabilitas

\begin{tabular}{|l|c|c|c|}
\hline \multicolumn{1}{|c|}{ Variabel } & Koefisien Alpha & $\mathrm{r}_{\text {tabel }} 5 \%$ & Interpretasi \\
\hline Konsentrasi Belajar & 0,979 & 0,235 & Reliabel \\
\hline Intensitas Belajar & 0,964 & 0,235 & Reliabel \\
\hline
\end{tabular}

Sumber Data: Lampiran

Dari hasil perhitungan Alpha Cronbach tersebut dikonsultasikan pada $\mathrm{r}$ tabel dengan taraf signifikansi $5 \%$ dan pada $\mathrm{db}=\mathrm{N}-1=71-1=70$ yang besarnya $=$ 0,235, maka dapat dikatakan instrumen tersebut reliabel, karena nilai $\mathrm{r}$ hitung lebih besar dari nilai $r$ tabel $(0,979>0,235)$ untuk konsentrasi belajar begitu juga dengan intensitas belajar $(0,964>0,235)$.

\section{b. Pengujian Hipotesis}


Setelah dilakukan uji prasyarat validitas dan reabilitas analisis selanjutnya dapat dilakukan pengujian hipotesis untuk mengetahui apakah hipotesis yang telah dirumuskan sebelumnya diterima atau ditolak. Adapun langkah-langkah pengujian hipotesis dalam penelitian ini sebagai berikut:

\section{Analisis Korelasi Sederhana}

Tabel 4. Hasil Uji Hipotesis $\left(\mathrm{X}_{1}\right)$ terhadap (Y)

\begin{tabular}{|rl|r|r|r|}
\hline \multicolumn{4}{|c|}{ Correlations } \\
\hline Pearson Correlation & X1 & X2 & \multicolumn{1}{c|}{ Y } \\
X1 & 1 &, $571^{* *}$ &, $871^{* *}$ \\
& Sig. (2-tailed) & &, 000 &, 000 \\
& N & 71 & 71 & 71 \\
& Pearson Correlation &, $571^{* *}$ & 1 &, $663^{* *}$ \\
X2 Sig. (2-tailed) &, 000 & &, 000 \\
& N & 71 & 71 & 71 \\
& Pearson Correlation &, $871^{* *}$ &, $663^{* *}$ & 1 \\
Sig. (2-tailed) &, 000 &, 000 & 71 \\
\hline
\end{tabular}

**. Correlation is significant at the 0.01 level (2-tailed).

Sumber data : Lampiran hasil SPSS

Berdasarkan hasil perhitungan korelasi product moment dari Pearson, dan didukung dengan bantuan program SPSS diatas didapat nilai $r$ hitung sebesar 0,571. Jadi terdapat pengaruh konsentrasi belajar terhadap kemampuan berpikir kritis peserta didik sebesar 0,571 .

Untuk menghitung besarnya sumbangan (koefisien determinan atau koefisien penentu) variabel konsetrasi belajar terhadap variabel kemampuan berpikir kritis dengan rumus:

$$
\begin{aligned}
\mathrm{KP} & =\mathrm{r}^{2} \cdot 100 \% \\
& =0,571^{2} \cdot 100 \% \\
& =32,60 \%
\end{aligned}
$$

Artinya: pengaruh konsentrasi belajar terhadap kemampuan berpikir kritis peserta didik memberikan sumbangan sebesar 32,60\%, sedangkan sisanya 67,40\% adalah pengaruh variabel lain yang tidak diteliti oleh penulis. 
Tabel 5. Uji Signifikasi $\left(\mathrm{X}_{1}\right)$ terhadap $(\mathrm{Y})$

\begin{tabular}{|c|c|c|c|c|c|c|}
\hline \multicolumn{7}{|c|}{ Coefficients $^{a}$} \\
\hline \multirow{2}{*}{\multicolumn{2}{|c|}{ Model }} & \multicolumn{2}{|c|}{ Unstandardized Coefficients } & \multirow{2}{*}{$\begin{array}{l}\text { Standardized } \\
\text { Coefficients } \\
\text { Beta }\end{array}$} & \multirow[t]{2}{*}{$\mathrm{t}$} & \multirow[t]{2}{*}{ Sig. } \\
\hline & & B & Std. Error & & & \\
\hline \multirow{3}{*}{1} & (Constant) & $-17,697$ & 5,941 & & $-2,979$ &, 004 \\
\hline & $\mathrm{X} 1$ & 2,520 & ,229 & ,730 & 11,019 &, 000 \\
\hline & $\mathrm{X} 2$ & ,667 & , 179 & ,246 & 3,714 &, 000 \\
\hline
\end{tabular}

a. Dependent Variable: $Y$

(Sumber: Data Peneliti dengan SPSS)

Berdasarkan data di atas, dengan ketentuan tingkat kesalahan $\alpha=0,05 ; \mathrm{db}=\mathrm{n}$ $-2=71-2$ sehingga di dapat $\mathrm{t}$ tabel $=3,130$. Ternyata $\mathrm{t}$ hitung $\leq \mathrm{t}$ tabel atau 11,019 $\geq 3,130$ maka ada pengaruh yang signifikan untuk variabel konsentrasi belajar terhadap kemampuan berpikir kritis. Sehingga dapat disimpulkan bahwa hipotesis pertama yang diajukan diterima.

Tabel 6 : Hasil Uji Hipotesis $\left(\mathrm{X}_{2}\right)$ terhadap (Y)

\begin{tabular}{|c|c|c|c|c|}
\hline \multicolumn{5}{|c|}{ Correlations } \\
\hline & & $\mathrm{X} 1$ & $\mathrm{X} 2$ & $Y$ \\
\hline \multirow{4}{*}{$\mathrm{X} 1$} & Pearson Correlation & 1 &, $571^{\star *}$ &, $871^{* *}$ \\
\hline & Sig. (2-tailed) & & ,000 & ,000 \\
\hline & $\mathrm{N}$ & 71 & 71 & 71 \\
\hline & Pearson Correlation &, $571^{\star \star}$ & 1 &, $663^{* \star}$ \\
\hline \multirow[t]{3}{*}{$x 2$} & Sig. (2-tailed) &, 000 & & ,000 \\
\hline & $\mathrm{N}$ & 71 & 71 & 71 \\
\hline & Pearson Correlation &, $871^{\star *}$ &, $663^{* *}$ & 1 \\
\hline \multirow[t]{2}{*}{ Y } & Sig. (2-tailed) &, 000 &, 000 & \\
\hline & $\mathrm{N}$ & 71 & 71 & 71 \\
\hline
\end{tabular}

**. Correlation is significant at the 0.01 level (2-tailed).

Berdasarkan hasil perhitungan korelasi product moment dari Pearson, dan didukung dengan bantuan program SPSS diatas didapat nilai r hitung sebesar 0,871. Jadi, terdapat pengaruh intensitas belajar terhadap kemampuan berpikir kritis peserta 
didik sebesar 0,871. Memberikan sumbangan 75,86 \%. sedangkan sisanya 24,14\% adalah pengaruh variabel lain yang tidak diteliti oleh penulis.

Berdasarkan data tabel 5, dengan ketentuan tingkat kesalahan $\alpha=0,05 ; \mathrm{db}=\mathrm{n}$ $-2=71-2$ sehingga di dapat $\mathrm{t}$ tabel $=3,130$. Ternyata $\mathrm{t}$ hitung $\leq \mathrm{t}$ tabel atau 3,714 $\geq$ 3,130 maka ada pengaruh yang signifikan untuk variabel intensitas belajar terhadap kemampuan berpikir kritis. Sehingga dapat disimpulkan bahwa hipotesis kedua yang diajukan diterima.

\section{Analisis Korelasi Berganda}

Tabel 7: Hasil Analisis Korelasi Berganda

Model Summary

\begin{tabular}{|l|r|r|r|c|}
\hline Model & $\mathrm{R}$ & $\mathrm{R}$ Square & \multicolumn{1}{|c|}{$\begin{array}{c}\text { Adjusted R } \\
\text { Square }\end{array}$} & $\begin{array}{c}\text { Std. Error of the } \\
\text { Estimate }\end{array}$ \\
\hline 1 &, $894^{\mathrm{a}}$ &, 799 &, 793 & 4,880023 \\
\hline
\end{tabular}

a. Predictors: (Constant), X2, X1

(Sumber: Data Peneliti dengan SPSS)

Berdasarkan hasil perhitungan korelasi ganda product moment dari Pearson, dan didukung dengan bantuan program SPSS diatas didapat nilai $\mathrm{r}$ hitung sebesar 0,894. Jadi, terdapat pengaruh konsentrasi dan intensitas belajar terhadap kemampuan berpikir kritis peserta didik sebesar 0,894 dan memberikan sumbangan sebesar memberikan sumbangan sebesar 79,92\%, sedangkan sisanya 20,08\% adalah pengaruh variabel lain yang tidak diteliti oleh penulis.

Tabel 8 : Uji Signifikasi (X) Terhadap (Y)

\begin{tabular}{|rl|r|r|r|r|r|}
\hline \multicolumn{1}{|c|}{ ANOVA $^{\mathrm{a}}$} & \\
\hline & & Sum of Squares & \multicolumn{1}{c|}{$\mathrm{df}$} & Mean Square & \multicolumn{1}{c|}{$\mathrm{F}$} & \multicolumn{1}{c|}{ Sig. } \\
\hline & Regression & 6424,915 & 2 & 3212,458 & 134,894 &, $000^{\mathrm{b}}$ \\
& Residual & 1619,394 & 68 & 23,815 & & \\
& Total & 8044,310 & 70 & & & \\
\hline
\end{tabular}

a. Dependent Variable: $Y$

b. Predictors: (Constant), X2, X1 
Berdasarkan data diatas dengan ketentuan tingkat kesalahan $\alpha=0,05$; di dapat $\mathrm{F}$ hitung $=25,06$ sedangkan $\mathrm{F}$ tabel $=3,130$. Ternyata $\mathrm{F}$ hitung $\geq \mathrm{F}$ tabel atau 134,894 $\geq 3,130$ maka ada pengaruh yang signifikan variabel pengaruh konsentrasi dan intensitas belajar terhadap kemampuan berfikir kritis peserta didik pada mata pelajaran ekonomi di MA Sarji Ar Rasyid Dawuhan Situbondo semester ganjil tahun pelajaran 2020/2021. Sehingga dapat disimpulkan bahwa hipotesis mayor yang diajukan diterima.

\section{PEMBAHASAN}

Setelah dilakukan analisis data untuk pengujian hipotesis kemudian dilakukan pembahasan hasil analisis data. Pembahasan analisis data sebagai berikut:

\section{Pengaruh Konsentrasi Belajar $\left(\mathrm{X}_{1}\right)$ terhadap Kemampuan Berpikir Kritis Peserta didik (Y)}

Pada penelitian ini menunjukkan bahwa terdapat pengaruh positif dan signifikan pengaruh konsetrasi belajar terhadap kemampuan berpikir kritis peserta didik. Hal tersebut dibuktikan dari hasil analisis yang menggunakan korelasi sederhana product moment diperoleh nilai koefisien korelasi $\left(\mathrm{r}_{\mathrm{x} 1 \mathrm{y}}\right)$ sebesar 0,571 dan nilai koefisien penentu atau determinan (KP) sebesar 32,60\% yang berarti variabel konsentrasi belajar memberikan sumbangan sebesar 32,60 \% terhadap kemampuan berpikir kritis peserta didik.

Untuk mengetahui tingkat signifikan dan apakah hipotesa minor pertama yang diajukan terima/ ditolak, dilakukan uji t. Dari hasil perbandingan $t_{\text {hitung dengan taraf }}$ signifikansi $5 \%$ dengan $\mathrm{db}=\mathrm{n}-2=71-2$ sehingga di dapat $\mathrm{t}_{\text {tabel }}=3,130$ sedangkan $t_{\text {hitung }}$ sebesar 11,019. Jadi $t_{\text {hitung }}$ lebih besar dari tabel artinya hipotesa kerja (Ha) diterima dan hipotesa nihil (Ho) ditolak, hipotesa kerja yang diterima adalah: "Ada pengaruh konsentrasi belajar terhadap kemampuan berpikir kritis peserta didik”. 
Tabel 9 : Interprestasi koefisien korelasi

\begin{tabular}{cl}
\hline Besar nilai $\mathbf{r}$ & \multicolumn{1}{c}{ Interprestasi } \\
\hline Antara $\pm 0,00 \mathrm{~s} / \mathrm{d} \pm 0,20$ & Tidak ada pengaruh \\
Antara $\pm 0,21 \mathrm{~s} / \mathrm{d} \pm 0,40$ & Pengaruh rendah \\
Antara $\pm 0,41 \mathrm{~s} / \mathrm{d} \pm 0,60$ & Pengaruh sedang \\
Antara $\pm 0,61 \mathrm{~s} / \mathrm{d} \pm 0,80$ & Pengaruh tinggi \\
Antara $\pm 0,81 \mathrm{~s} / \mathrm{d} \pm 1,00$ & Pengaruh sempurna \\
\hline
\end{tabular}

\section{Sumber data : Riduwan}

Setelah dikonsultasikan dengan hasil tebel interprestasi di atas, maka nilai 0,571 terletak antara $\pm 0,61 \mathrm{~s} / \mathrm{d} \pm 0,80$ berarti pengaruh konsentrasi belajar terhadap kemampuan berpikir kritis adalah pengaruh tinggi.

Hasil penelitian ini sesuai dengan beberapa pendapat ahli diantaranya, Menurut Handy Susanto (2006 : 46) berpendapat bahwa konsentrasi merupakan kemampuan seseorang untuk bisa mencurahkan perhatian dalam waktu yang relatif lama. Seorang anak dikatakan dapat berkonsentrasi pada pelajaran apabila dapat memusatkan perhatian pada apa yang dipelajari. Semakin banyak informasi yang harus diserap oleh siswa maka kemampuan berkonsentrasi harus dimiliki dalam proses belajar.

\section{Pengaruh Intensitas Belajar $\left(\mathrm{X}_{2}\right)$ terhadap Kemampuan Berpikir Kritis Peserta Didik (Y)}

Pada penelitian ini menunjukkan bahwa terdapat pengaruh positif dan signifikan pengaruh intensitas belajar terhadap kemampuan berpikir kritis peserta didik. Hal tersebut dibuktikan dari hasil analisis yang menggunakan korelasi sederhana product moment diperoleh nilai koefisien korelasi $\left(\mathrm{r}_{\mathrm{x} 2 \mathrm{y}}\right)$ sebesar 0,871 dan nilai koefisien penentu atau determinan (KP) sebesar 75,86 \% yang berarti variabel intensitas belajar hanya memberikan sumbangan sebesar 75,86\% terhadap kemampuan berpikir kritis peserta didik. 
Untuk mengetahui tingkat signifikan dan apakah hipotesa minor kedua yang diajukan terima/ ditolak, dilakukan uji t. Dari hasil perbandingan $t_{\text {hitung dengan taraf }}$ signifikansi $5 \%$ dengan $\mathrm{db}=\mathrm{n}-2=71-2$ sehingga di dapat $\mathrm{t}_{\text {tabel }}=3,130$ sedangkan

$\mathrm{t}_{\text {hitung }}$ sebesar 3,714. Jadi $\mathrm{t}_{\text {hitung }}$ lebih besar dari $\mathrm{t}_{\text {tabel }}$ artinya hipotesa kerja (Ha) diterima dan hipotesa nihil (Ho) ditolak, hipotesa kerja yang diterima adalah: "Ada pengaruh intensitas belajar terhadap kemampuan berpikir kritis peserta didik"

Setelah dikonsultasikan dengan hasil tebel interprestasi, maka nilai 0,871 terletak antara $\pm 0,81 \mathrm{~s} / \mathrm{d} \pm 1,00$ berarti pengaruh intensitas belajar terhadap kemampuan berpikir kritis adalah pengaruh sempurna. Hasil tersebut konsisten dengan pendapat Nurkholif Hazim (2015:191), intensitas adalah kebulatan tenaga yang dikerahkan untuk suatu usaha intensitas sangat erat kaitannya dengan motivasi, antara keduanya tidak dapat dipisahkan. Intensitas merupakan realitas dari motivasi dalam rangka mencapai tujuan yang diharapkan yaitu peningkatan prestasi, sebab seseorang melakukan usaha dengan penuh semangat karena adanya motivasi sebagai pendorong pencapaian prestasi..

\section{Pengaruh Konsentrasi dan Intensitas Belajar terhadap Kemampuan Berpikir Kritis Peserta Didik (Y)}

Pada penelitian ini menunjukkan bahwa terdapat pengaruh positif dan signifikan konsentrasi dan intensitas belajar terhadap kemampuan berpikir kritis peserta didik. Hal tersebut dibuktikan dari hasil analisis yang menggunakan korelasi sederhana product moment diperoleh nilai koefisien korelasi $\left(\mathrm{r}_{\mathrm{yx} 1 \times 2}\right)$ sebesar 0,894 dan nilai koefisien penentu atau determinan (KP) sebesar 79,92\% yang berarti variabel konsentrasi dan intensitas belajar hanya berpengaruh sebesar 0,894 dengan tingkat korelasi terletak antara $\pm 0,81 \mathrm{~s} / \mathrm{d} \pm 1,00$ berarti pengaruh konsentrasi dan intensitas belajar terhadap kemampuan berpikir kritis adalah pengaruh sempurna pada mata pelajaran ekonomi.

Untuk mengetahui tingkat signifikan dan apakah hipotesa mayor yang diajukan terima/ ditolak, dilakukan uji F .Dari hasil perbandingan $F_{\text {hitung dengan taraf }}$ signifikansi $5 \%$ dengan $\mathrm{db}=\mathrm{n}-2=71-2$ sehingga di dapat $\mathrm{F}_{\text {tabel }}=3,13$ sedangkan

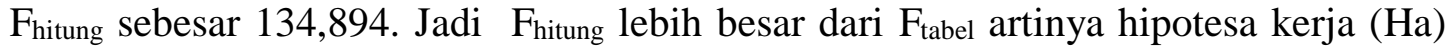

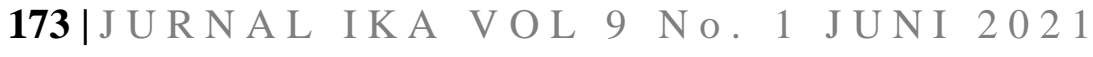


diterima dan hipotesa nihil (Ho) ditolak, hipotesa kerja yang diterima adalah: "Ada pengaruh konsentrasi dan intensitas belajar terhadap kemampuan berpikir kritis peserta didik". Berdasarkan analisis data tersebut yang dominan mempengaruhi kemampuan berpikir kritis peserta didik adalah intensitas belajar yang memberikan pengaruh sebesar 0,871 bila di bandingkan dengan variabel konsentrasi belajar yang hanya memberikan pengaruh sebesar 0,571 .

\section{KESIMPULAN}

Berdasarkan hasil penelitian, analisa data dan pengujian hipotesa penulis, maka dapat diambil kesimpulan sebagai berikut :

a. Ada pengaruh konsentrasi dan intensitas belajar terhadap kemampuan berfikir kritis peserta didik pada mata pelajaran ekonomi di MA Sarji Ar Rasyid Dawuhan Situbondo semester ganjil tahun pelajaran 2020/2021 sebesar 0,892.

b. Ada pengaruh konsentrasi belajar terhadap kemampuan berfikir kritis peserta didik pada mata pelajaran ekonomi di MA Sarji Ar Rasyid Dawuhan Situbondo semester ganjil tahun pelajaran 2020/2021 sebesar 0,571.

c. Ada pengaruh intensitas belajar terhadap kemampuan berfikir kritis peserta didik pada mata pelajaran ekonomi di MA Sarji Ar Rasyid Dawuhan Situbondo semester ganjil tahun pelajaran 2020/2021 sebesar 0,871.

Berdasarkan kesimpulan di atas, maka penulis dapat memberikan saran saran sebagai berikut :

1. Bagi lembaga MA Sarji Ar Rasyid, hendaknya lebih memperhatikan dan meningkatkan mutu/ kualitas guru pengajaran melalui konsentrasi dan intensitas dalam belajar.

2. Bagi Guru, hendaknya lebih meningkatkan bimbingan kepada peserta didik dan memberikan masukan bagi guru tentang arti pentingnya konsentrasi dan intensitas dalam belajar yang menunjang prestasi belajar peserta didik.

3. Bagi peneliti lain, apabila hendak mengadakan penelitian yang sejenis maka penulisan saranan untuk meneliti semua faktor yang ada kaitannya dengan kemampuan berpikir siswa. 


\section{DAFTAR PUSTAKA}

Abdul Majid 2007, Perencanaan Pembelajaran Mengembangkan Standar Kompetensi Guru, Bandung, PT. Remaja Rosdakarya

Arikunto, S. 2008. Prosedur Penelitian Suatu Pendekatan Praktek. Jakarta: Renika Cipta

Bafadal Ibrahim 2013, Manajemen Perlengkapan Sekolah Teori dan Aplikasinya Jakarta PT. Bumi Aksara

Cholid Narbuko dan Abu Ahmad, 2003, Metodologi Penelitian, Jakarta: PT. Bumi Aksara.

Dalyono, M. 2011, Psikologi Pendidikan. Jakarta PT. Rineka Cipta

Djamarah Bahri. S, 2012, Strategi Belajar Mengajar Jakarta, PT. Rineka Cipta

Hadi, S, 2011. Metodologi Research Jilid I. Yogyakarta: Andi Offset

Hakim, Tharsan, 2011, Belajar Secara Efektif, Jakarta Paspa Swara

Hasbullah, 2011, Dasar-dasar Ilmu Pendidikan, PT, Raja Grafindo Persada, Jakarta

Mudjiono, Dimiyati, 2009, Belajar dan Pembelajaran Jakarta, Rineka Cipta

Nasution S, 2014, Teknologi Pendidikan Jakarta, PT. Karya Unipress

Oemar Hamalik, 2012 Belajar Dan Faktor-faktor Yang Mempengaruhinya. Jakarta : Rineka Cipta

Slameto, 2005, Teknologi Dan Faktor-Faktor yang mempengaruhinya, Jakarta PT. Rineka Cipta.

Suharsimi Arikunto. 2009. Metodologi Penelitian. Jakarta. PT Rineka Cipta.

Supriono Subakir Ahmad Supari, 2011 Manajemen Berbasis Sekolah IKAPI Cabang Jatim

Syaiful Bahri Djamarah 2009, Rahasia Sukses Belajar, Jakarta PT. Rineka Cipta Syaiful Sagala, 2007, Manajemen Strategi Dalam Peningkatan Mutu Pendidikan Bandung, CV. Alfabeta

Yamin Riyanto. 2003. Metodologi Penelitian III. Jakarta PT Bumi Aksara. 